\title{
1. Introduction to the Research Handbook on EU Disability Law
}

\author{
Delia Ferri and Andrea Broderick
}

\section{DISABILITY LAW AS AN EMERGING FIELD OF EUROPEAN UNION LAW}

In the past 20 years, the European Union (EU) has adopted a wide range of legislative measures addressing, to varying degrees, the rights of persons with disabilities. It has also put forward various policy initiatives to complement, as well as to boost the effects of, those measures. Well-established scholarship has highlighted that the major drivers of the development of this complex net of EU legislation and policies were, ${ }^{1}$ first, the entry into force of the Treaty of Amsterdam, and second, the conclusion by the $\mathrm{EU}^{2}$ of the UN Convention on the Rights of Persons with Disabilities (CRPD or UN Convention). ${ }^{3}$

Before 1999, the former European Community (EC) had addressed disability mainly through the use of soft law and by means of programmes aimed at supporting Member States' actions. ${ }^{4}$ The Treaty of Amsterdam conferred a sound competence on the EC to combat, inter alia, disability discrimination, by virtue of Article 13 EC (now Article 19 of the Treaty on the Functioning of the European Union - TFEU). This constitutional change prompted the adoption of Directive 2000/78/EC, ${ }^{5}$ establishing a general framework for equal treatment in

1 See generally Lisa Waddington, From Rome to Nice in a Wheelchair: The Development of a European Disability Policy (Europa Law Publishing 2005). See also Gerard Quinn, 'The Human Rights of People with Disabilities under EU Law' in Philip Alston, Mara R Bustelo and James Heenan (eds), The EU and Human Rights (Oxford University Press 1999) 281-326; see further Lisa Waddington, 'The Influence of the UN Convention on the Rights of Persons with Disabilities on EU Anti-discrimination Law' in Uladzislau Belavusau and Kristin Henrard (eds), EU Anti-discrimination Law beyond Gender (Hart Publishing 2018) 339-61.

2 Council Decision 2010/48/EC concerning the conclusion, by the European Community, of the United Nations Convention on the Rights of Persons with Disabilities [2010] OJ L23/35.

3 Annex I UN Convention on the Rights of Persons with Disabilities, 13 December 2006, in force 03 May 2008, UN Doc. A/RES/61/106.

4 Mark Priestley, 'In Search of European Disability Policy: Between National and Global' (2007) 1 ALTER - Revue Européenne de recherche sur l'handicap 61.

5 This Research Handbook does not discuss the constitutional nature of the EU, and it does not endeavour to contribute to the scholarly debate on the constitutionalization of the EU. However, it refers to the Treaties and the EU Charter of Fundamental Rights (CFR) as the constitutional acts of the EU, in line with the Court of Justice of the European Union (CJEU) case law. See, to this effect, Case C-621/18 Andy Wightman EU:C:2018:999, para 44: '[i]n that respect, it must be borne in mind that the founding Treaties, which constitute the basic constitutional charter of the European Union (judgment of 23 April 1986, Les Verts v Parliament, 294/83, EU:C:1986:166, paragraph 23), established, unlike ordinary international treaties, a new legal order, possessing its own institutions, for the benefit of which the Member States thereof have limited their sovereign rights, in ever wider fields, and the subjects of which comprise not only those States but also their nationals'. 
employment and occupation (Employment Equality Directive), ${ }^{6}$ which marked the first legislative intervention designed to address discrimination on the ground of disability. The Treaty of Amsterdam also included a Declaration stating that the EU institutions must take account of the needs of persons with disabilities in drawing up measures under the former Article $95 \mathrm{EC}$ (now Article 114 TFEU). That Declaration encouraged the use of internal market legislation to address, where feasible, the rights of persons with disabilities.

The EU Charter of Fundamental Rights (CFR or Charter), ${ }^{7}$ proclaimed in 2000, gave a renewed focus to the rights of people with disabilities by including, alongside an all-embracing prohibition of discrimination (Article 21 CFR), a provision on the integration of persons with disabilities in society (Article 26 CFR). However, the Charter per se did not stimulate the development of EU disability policies. The arguably limited effects of the Charter are related, on the one hand, to its initial lack of binding force, as the Charter only acquired the same legal status as the Treaties in 2009 , following the entry into force of the Treaty of Lisbon; and, on the other hand, to the fact that the Charter was never intended to expand the reach of EU legislation. In its original formulation, Article 51(2) CFR stated that the Charter did not 'establish any new power or task for the Community or the Union, or modify powers and tasks defined by the Treaties'. That provision still constitutes a blatant limitation on the operation of the Charter, even in its slightly amended formulation.

The second major driver of the development of EU disability law and policy was, as mentioned above, the conclusion by the EU (alongside its Member States) of the CRPD, which occurred approximately ten years after the entry into force of the Treaty of Amsterdam. The need to comply with the wide-ranging obligations provided for in the CRPD gave rise to an immediate and visible shift in the EU's approach to disability. While the entry into force of the Treaty of Amsterdam had resulted in a qualitative and quantitative shift in the EU action - allowing for the adoption of EU secondary law addressing the rights of persons with disabilities - the ratification of the CRPD has triggered a more substantive change. In the first instance, the promotion of the rights of persons with disabilities became a priority and a key area of action for the EU. In the second instance, a social model of disability has been creeping into $\mathrm{EU} \mathrm{law}^{8}$ - as will be discussed further in this Research Handbook - mainly through the jurisprudence of the Court of Justice of the EU (CJEU). After the ratification of the CRPD, the European Disability Strategy 2010-2020 (EDS) ${ }^{9}$ was adopted, with the express aim to implement the UN Convention. It represents the first evidence of the shift in the Union's approach to disability. The EDS elaborates a comprehensive policy framework on disability, and identifies cross-cutting EU-level actions and new legislative measures that span the whole spectrum of EU competences. The EDS has, in itself, contributed to the emergence of the self-standing field of 'EU disability law', which is arguably the newest (and one of the most dynamic) fields of EU law. Recent developments, such as the publication of the European Accessibility Act in

\footnotetext{
6 Council Directive 2000/78/EC establishing a general framework for equal treatment in employment and occupation [2000] OJ L303/16.

7 Charter of Fundamental Rights of the European Union [2000] OJ C364/1. On the CFR, see, among many others, Robert Schütze, European Constitutional Law (Cambridge University Press 2012) 422-28.

8 See, among many others, Tom Shakespeare and Nicholas Watson, 'The Social Model of Disability: An Outdated Ideology?' (2001) 2 Research in Social Science and Disability 9.

9 Commission, 'European Disability Strategy 2010-2020: A Renewed Commitment to a Barrier-Free Europe’ COM (2010) 636 final.
} 
the Official Journal of the EU (OJ) in June $2019,{ }^{10}$ suggest that the dynamism of EU disability law is destined to continue.

Interestingly, the entry into force of the Treaty of Lisbon, which had the result that the CFR acquired constitutional status, took place almost concurrently with the ratification of the CRPD, in December 2009. The Treaty of Lisbon has clarified (and, to some extent, extended) EU competences; placed a major emphasis on human rights protection; included among its own objectives those of combating social exclusion and discrimination and promoting social justice; and included a reference to a 'social market economy'. Moreover, it has introduced two cross-cutting clauses that allow the EU to mainstream social considerations (broadly conceived) in its internal market legislation. In that regard, Article 9 TFEU states that:

[i]n defining and implementing its policies and activities, the Union shall take into account requirements linked to the promotion of a high level of employment, the guarantee of adequate social protection, the fight against social exclusion, and a high level of education, training and protection of human health.

In addition, Article 10 TFEU requires that, 'in defining and implementing its policies and activities, the Union shall aim to combat discrimination based on [...] disability [...]', allowing the EU to integrate the fight against disability discrimination into all EU actions. Yet, the Treaty of Lisbon has neither altered the limited scope of EU social policy per se nor the Union's competence in this domain. Moreover, that Treaty did not inject many references to disability into the EU's constitutional framework. Article 19 TFEU, the legal basis for the adoption of EU non-discrimination and equality legislation, remains the core provision explicitly related to the rights of persons with disabilities. Hence, the renewed constitutional framework has only facilitated, rather than prompted, the development of a pan-European disability law.

Against this background, and approximately ten years after the conclusion of the CRPD and the release of the EDS, on the tenth anniversary of the entry into force of the Treaty of Lisbon, the time seems ripe to reflect on the current status of EU disability law and to discuss the challenges that lie ahead. In that vein, this first Research Handbook on EU Disability Law includes various contributions that address, from different angles and perspectives, key questions related to the scope and effects of EU disability law, its compliance with the CRPD and the gaps that remain to be filled. All of the chapters, either expressly or implicitly, refer to the scant attention paid to disability until the ratification of the UN Convention by the EU. Many chapters critically discuss whether the somewhat commercially driven nature of the EU is undermining the adoption of a human rights approach to disability. Several contributions highlight how the CRPD, and more generally international human rights law, has supported the mainstreaming of disability in EU legislation. Each chapter adopts a different perspective (which does not necessarily reflect that of the editors) on the current EU legal framework, discussing the extent to which the rights of persons with disabilities are protected in various spheres of EU law. On the whole, the Research Handbook traces the boundaries of EU disability law as a distinct field of research, highlighting the interconnection between the development of the EU disability agenda and the conclusion of the CRPD.

10 Directive (EU) 2019/882 on the accessibility requirements for products and services [2019] OJ L151/70. 


\section{THE UN CONVENTION ON THE RIGHTS OF PERSONS WITH DISABILITIES AS THE NORMATIVE STANDARD OF ANALYSIS}

In analysing various facets of EU disability law, this Research Handbook refers to the CRPD not only as a driver of policy development at the supranational level, but also as the normative standard to which the EU adheres with regard to the rights of individuals with disabilities. The Research Handbook does not engage to any great extent with the CRPD itself. However, all of the chapters cite relevant CRPD provisions or relevant jurisprudence, to ascertain the extent to which EU law complies with the obligations laid out in the UN Convention. On the whole, this Research Handbook endeavours to investigate the extent to which the EU protects and fulfils the rights set out in the Convention. It is well known that the CRPD aims to "promote, protect and ensure the full and equal enjoyment of all human rights and fundamental freedoms by all persons with disabilities, and to promote respect for their inherent dignity'. ${ }^{11}$ Scholars claim that the CRPD has 'modified, transformed and added to traditional human rights concepts in key respects'; ${ }^{12}$ and as suggested by de Beco, the CRPD also blurs the distinction between the traditional categories of civil and political rights, on the one hand, and social, economic and cultural rights, on the other hand. ${ }^{13}$

Alongside the recognition that human rights and fundamental freedoms must be realized for people with disabilities in order for them to meaningfully participate in society on an equal basis with others, the CRPD endorses the shift from the medical model of disability - which perceives the inability of people with disabilities to participate in society as the inevitable result of their own impairment rather than as a consequence of any disabling and discriminatory barriers in society ${ }^{14}$ - to the social-contextual model of disability. ${ }^{15}$ The latter model is a more refined elaboration of the 'pure' social model, which attracted much criticism on account of the fact that it focused on societal barriers (physical, attitudinal and legislative, among others), and neglected the role of impairment in disabling the individual concerned. ${ }^{16}$ In that connection, the social-contextual model recognizes that 'disability results from the interaction between persons with impairments and attitudinal and environmental barriers

\footnotetext{
11 Article 1 CRPD.
}

12 Rosemary Kayess and Philip French, 'Out of Darkness into Light? Introducing the Convention on the Rights of Persons with Disabilities' (2008) 8(1) Human Rights Law Review 32.

13 See generally Gauthier De Beco, 'The Indivisibility of Human Rights in Light of the Convention on the Rights of Persons with Disabilities' (2019) 68(1) International and Comparative Law Quarterly 141.

14 Andrea Broderick, The Long and Winding Road to Equality and Inclusion for Persons with Disabilities: The United Nations Convention on the Rights of Persons with Disabilities (Intersentia 2015) 1.

15 The term 'social-contextual model' (in connection with the CRPD) was coined by Broderick, The Long and Winding Road to Equality and Inclusion for Persons with Disabilities (n 14) 77. Several authors still refer to the CRPD as purporting the social model of disability (e.g. Anna Arstein-Kerslake, Restoring Voice to People with Cognitive Disabilities: Realizing the Right to Equal Recognition before the Law (Cambridge University Press 2017) 72).

16 For a critique of this aspect of the social model, see Deborah Marks, 'Dimensions of Oppression: Theorising the Embodied Subject' (1999) 14(5) Disability \& Society 661. See also Jenny Morris, Pride against Prejudice: Transforming Attitudes to Disability. A Personal Politics of Disability (Women's Press 1991) 10. 
that hinder their full and effective participation in society on an equal basis with others'. ${ }^{17}$ This social-contextual conceptualization of disability informs the analysis carried out in the various chapters compiled in this Research Handbook. Consistently with this conceptualization, the various contributions adhere to the 'language of rights', and - as far as possible - to 'people-first language', ${ }^{18}$ which is used in the CRPD (as well as in the English versions of EU legislation and case law). ${ }^{19}$ The term 'persons/people with disabilities' is used for the most part. However, some authors refer occasionally to 'disabled persons/people' - but always in line with the CRPD's understanding of disability.

While the social-contextual model of disability defines how disability arises and explains the marginalization of people with disabilities, the substantive provisions of the UN Convention embrace the human rights model of disability. ${ }^{20}$ The latter model builds on the social-contextual model in that it recognizes that 'disability is a social construct' ${ }^{21}$ However, it goes further in conceiving of disability as 'one of several layers of identity' and in placing emphasis on human dignity. ${ }^{22}$ Without delving deeply into a discussion of the human rights model of disability, whose traits will emerge across the various contributions in this Research Handbook, it suffices to point out that it is informed by the general principles listed in Article 3 CRPD. Among them is the recognition of the inherent dignity of people with disabilities, and of their individual autonomy and independence. People with disabilities are to be valued because of their self-worth, according to the human rights model. Alongside dignity as a cornerstone of the UN Convention, the principle of non-discrimination has been described as the 'leitmotif' of the CRPD, ${ }^{23}$ as it cuts across both civil and political rights, such as the right to legal capacity; and economic, social and cultural rights, such as the right to education. Article 2 CRPD provides a broad definition of discrimination on the basis of disability, highlighting that such discrimination includes the denial of reasonable accommodation. The duty to reasonably accommodate is also defined in Article 2 CRPD as 'necessary and appropriate modification and adjustments', 'where needed in a particular case, to ensure to persons with disabilities the enjoyment or exercise on an equal basis with others of all human rights and fundamental freedoms'. The duty to provide reasonable accommodation must be

17 Preamble para (e), CRPD.

18 Phil Foreman, 'Language and Disability' (2005) 30(1) Journal of Intellectual and Developmental Disability 57.

19 The booklet 'Inclusive Communication in the GSC' also refers to the CRPD. See Council of the European Union, 'Inclusive Communication in the GSC' (General Secretariat of the Council 2018) www.consilium.europa.eu/media/35446/en_brochure-inclusive-communication-in-the-gsc.pdf accessed 7 February 2020. In that connection, it requires EU civil servants 'to be aware of and avoid negative stereotypes or stigmatising language'. The booklet suggests using person-first language (i.e. 'a person with a disability'), to 'emphasise each person's individuality and capabilities rather than defining them by a condition' and 'avoid phrases like "suffers from" and passive "victim” words'.

20 Committee on the Rights of Persons with Disabilities (CRPD Committee), General Comment No. 6 on equality and non-discrimination, UN Doc. CRPD/C/GC/6 (2018), para 11. On the human rights model of disability, see generally Theresia Degener, 'A New Human Rights Model of Disability' in Valentina Della Fina, Rachele Cera and Giuseppe Palmisano (eds), The United Nations Convention on the Rights of Persons with Disabilities: A Commentary (Springer 2017) 41-60.

21 CRPD Committee, General Comment No. 6 (n 20) para 11.

22 Ibid.

23 Oddny Mjöll Arnardóttir, 'A Future of Multidimensional Disadvantage Equality’ in Oddny Mjöll Arnardóttir and Gerard Quinn (eds), The UN Convention on the Rights of Persons with Disabilities: European and Scandinavian Perspectives (Martinus Nijhoff Brill 2009) 41-66, p. 41. 
distinguished from legal obligations to achieve accessibility, which is also a general principle of the CRPD - mentioned in Article 3, and whose obligations are laid down in Article 9. The latter provision requires States Parties to take appropriate measures to ensure that people with disabilities have access to environments, facilities, information and services on an equal basis with others. Accessibility duties are generalized (group-based) and anticipatory (not triggered by an individual request). ${ }^{24}$ The principle of participation and inclusion of people with disabilities in society is also a core feature of the UN Convention, and requires engagement 'with all persons, including persons with disabilities, to provide for a sense of belonging to and being part of society'. ${ }^{25}$ Ensuring participation of persons with disabilities is particularly important in fostering awareness-raising, and promoting respect for the rights and dignity of persons with disabilities. ${ }^{26}$

The foregoing principles and duties, which are intended to guide States Parties in implementing the CRPD, inform, to varying degrees (depending on the topic at stake), the contributions collected in this Research Handbook. Each contribution compares, to different extents, the scope of protection afforded by EU law to the rights provided for in the CRPD.

\section{THE SCOPE AND METHODOLOGY OF THE RESEARCH HANDBOOK}

The overall aims of this Research Handbook are to discuss the scope and effects of EU disability law, as well as to examine how the CRPD has been implemented to date in EU law and how its goals might be realized in the future. In order to achieve these objectives, the editors have carefully selected the topics to be covered in the Research Handbook on the basis of a systematic review of the relevant areas in which the CRPD has already influenced, or could potentially influence, the substantive provisions of EU law. This Research Handbook does not intend to replicate or reproduce pre-existing academic work. For this reason, while considering the historical legacy of the former Community disability policies, the various contributions focus on the present relationship between EU law and the CRPD, as well as on the extent to which disability rights are currently protected and promoted in EU law and policy. Notably, the Research Handbook also presents a wide range of future perspectives in the field.

The contributions in this Research Handbook were finalized, for the most part, by the beginning of January 2020. Thus, the Research Handbook as a whole covers legal developments that occurred up until the end of December 2019.

It is noteworthy that this Research Handbook focuses on EU law as such, and does not discuss national legislation. It also engages with the 'global reach' of EU law, ${ }^{27}$ to adopt an

24 Lisa Waddington and Andrea Broderick, Disability Law and the Duty to Reasonably Accommodate Beyond Employment: A Legal Analysis of the Situation in EU Member States (European Commission 2016) 45.

${ }_{25}$ CRPD Committee, General Comment No. 7 on the participation of persons with disabilities, including children with disabilities, through their representative organizations, in the implementation and monitoring of the Convention, UN Doc. CRPD/C/GC/7 (2018), paras 27 and 33.

26 Ibid para 76.

27 As noted by Fahey, ' $[\mathrm{t}]$ he global reach of EU law nowadays denotes a variety of situations where the EU acts as a "rule-exporter" to many countries, organisations and associations and gives its rules or compels others to take them, setting high standards or cohesive standards for a block of half a billion 
expression used by Fahey. ${ }^{28}$ Given the uncertainty surrounding the future relations between the United Kingdom (UK) and the EU after the UK's withdrawal from the Union, better known as 'Brexit', the Research Handbook does not include a chapter on Brexit and disability. A revised Withdrawal Agreement was agreed at the European Council, ${ }^{29}$ but at the time of writing the UK is in a transition period, and all EU law will remain applicable until the end of this period (the end of December 2020). ${ }^{30}$ The EU's willingness to maintain a close relationship with the UK has been evident throughout the negotiations related to the Withdrawal Agreement and has recently been expressed in a Commission Recommendation. ${ }^{31}$ However, the UK seems reluctant to engage in a partnership which extends beyond the boundaries of a trade agreement, given that it seeks to regain complete control of its external policy and economic choices and restrict immigration from other EU countries into the UK territory. ${ }^{32}$ Hence, as it stands, the contours of the future relationship between the EU and the UK are too blurred to predict with any degree of certainty the impact on the rights of persons with disabilities of Brexit - albeit that it can be presumed that this impact will most likely be negative.

In terms of methodology, the Research Handbook adopts a doctrinal approach, which, as is well known, involves examining the content of legal dicta, in order 'to evaluate whether it was effectively reasoned or to explore its implications for future cases' ${ }^{33}$ For the purpose of this Research Handbook, the use of traditional legal doctrinal methodology allows a focus to be maintained on the most relevant legal sources - legislative provisions, case law and academic scholarship - with a view to systematically interpreting them and clarifying the current state of the law. Comparative approaches will emerge at various junctures throughout the book. In the first instance, comparative elements will be evident when examining CJEU case law, since, as noted by Lenaerts, the CJEU is itself a 'comparative institution', situated 'at the crossroads of different, yet closely intertwined, legal cultures' ${ }^{34}$ In the second instance, comparative elements will emerge when comparing the level of protection afforded by the CRPD and that afforded by EU legislation, or when addressing relevant divergences or convergences between the EU legal order and that of the Council of Europe. On the whole, the methodology adopted throughout this book enables an evaluation of the extent to which disability rights and consid-

consumers, traders and enterprises and so on' (Elaine Fahey, 'The Global Reach of EU Law and Brexit: Between Theory and Praxis?' (2017) 20(1) Irish Journal of European Law 1, p. 17).

28 See generally Elaine Fahey, The Global Reach of EU Law (Routledge 2016).

29 Agreement on the withdrawal of the United Kingdom of Great Britain and Northern Ireland from the European Union and the European Atomic Energy Community [2019] OJ C384I/1.

30 Tobias Lock, 'One Foot In, the Other Foot Out: The Brexit Transition Period in the Withdrawal Agreement' (2019) https://papers.ssrn.com/sol3/papers.cfm?abstract_id=3352027 accessed 30 March 2020.

31 Commission, 'Recommendation for a Council Decision Authorising the Opening of Negotiations for a New Partnership with the United Kingdom of Great Britain and Northern Ireland' COM (2020) 35 final.

32 UK Government, 'The Future Relationship with the EU: The UK's Approach to Negotiations' (Presented to Parliament by the Prime Minister By Command of Her Majesty, 3 February 2020) https:// assets.publishing.service.gov.uk/government/uploads/system/uploads/attachment_data/file/868874/The _Future_Relationship_with_the_EU.pdf accessed 30 March 2020.

33 Emerson H Tiller and Frank B Cross, 'What Is Legal Doctrine' (2006) 100(1) Northwestern University Law Review 517, p. 518.

34 Koen Lenaerts, 'Interlocking Legal Orders in the European Union and Comparative Law' (2003) 52(4) International and Comparative Law Quarterly 873, p. 905. 
erations have been mainstreamed in existing EU law, and have prompted the development of new EU legislation and policy.

\section{THE STRUCTURE OF THE RESEARCH HANDBOOK}

This Research Handbook adopts a tripartite structure. Part I traces the history of EU disability law, and critically discusses the nature of the relationship between EU law and the CRPD. It examines whether the principles enshrined in the CRPD are reflected in EU disability law and policy on the whole. It provides the backdrop for the discussion conducted in Part II, which analyses different strands of EU legislation. That Part evaluates, through various lenses, the extent to which disability rights are protected and promoted in EU law and policy. It also discusses the changes that have been brought about in EU law by the conclusion of the CRPD, and presents the most up-to-date developments in the various domains in which the EU has exercised its competence to act in the field of disability. Part III looks beyond the EU and focuses on how disability has been relevant to date in EU external relations, as well as in the interrelation between EU law and other legal instruments and systems, such as the European Convention on Human Rights (ECHR) of the Council of Europe.

Each part of the Research Handbook attempts to provide original perspectives on the approach to disability adopted by the EU, and it highlights a sort of scaffold for the development of legal and policy solutions that comply with the CRPD. Issues that have recently gained prominence in the EU legislative agenda, such as accessibility, are examined in the Research Handbook at various junctures. All of the chapters engage critically and analytically with the existing legal framework(s). Many contributions raise questions for further discussion and highlight avenues for future research. The diversity of the authors' positions, reflections and personal views - a point which will be elaborated on in the concluding chapter of this Research Handbook - allows for a deep consideration of current understandings of how disability rights can be fulfilled in the EU internal market.

The first chapter of Part I - Chapter 2, co-authored by O'Mahony and Quinlivan - considers the development of European disability policy from the 1970s onwards, charting the evolution of policy that was rooted in the charity and medical models of disability, towards a human rights-based approach. Chapter 2 also explores how the CRPD will shape the post-2020 EU Disability Strategy, and how it will impact upon disability policy as a whole in the EU. Chapter 3, authored by Ferri, addresses the role of the CFR in protecting the rights of persons with disabilities. It critically discusses the extent to which the CJEU has referred to the Charter, and examines the interplay between the Charter and the CRPD. Chapter 4, authored by Chamon, analyses the CRPD from an EU perspective, focusing on its status and effects as a mixed agreement. In Chapter 5, Hoefmans examines the role of the EU institutions in contributing to the implementation and monitoring of the CRPD, and discusses the implementation of Article 33 CRPD at the EU level. Chapter 6, co-authored by Waddington and Broderick, analyses the extent to which people with disabilities participate in the EU policy system and the extent to which their right to political participation is protected under EU law. Chapter 7, authored by O'Sullivan, concludes Part I by examining the interaction between EU citizenship law and disability. That chapter adopts a theoretical approach and investigates the differences between the notion of 'social' citizenship that developed in the post-Second World War landscape and 
that of EU citizenship, ultimately reflecting on the complex relationship between disability and current Union citizenship norms.

Part II examines various strands of EU legislation. Each chapter looks at measures considered to fall within the category of 'positive integration', and analyses related case law, addressing the role of the CJEU in interpreting EU legislation. Where relevant, an analysis of soft law measures is also included. The chapters in Part II focus mainly on the post-Lisbon Treaty context, and they highlight changes that have occurred after the conclusion of the CRPD. While necessarily selective, Part II encompasses contributions that examine the most significant areas of EU law in which disability concerns have been mainstreamed and disability rights incorporated. At various junctures, the chapters highlight connections, overlaps, inconsistencies and remaining gaps in the field. The contributions in Part II identify and examine disability provisions in EU legislation, and trace 'disability patterns' in selected strands of legislation. They also discuss future perspectives and put forward novel solutions, designed to address - in a manner that is compliant with the CRPD - the gaps that exist in EU law with regard to protection of the rights of persons with disabilities.

Part II commences with a contribution - Chapter 8, co-authored by Broderick and Watson - on the most traditional field of disability action, that of non-discrimination and equality law. It examines the extent to which the current EU legal framework effectively protects persons with disabilities and discusses the most relevant CJEU jurisprudence in that regard. In Chapter 9, Vanhegen and Hendrickx investigate the extent to which disability rights are protected in EU labour law, beyond non-discrimination. The chapter considers the most recent developments with regard to ensuring active inclusion and full participation of disabled people in the labour market, and critically examines the contribution of the European Pillar of Social Rights (EPSR) in that connection. Van der Mei complements that analysis by focusing on social security regulations and the portability of disability benefits across the EU in Chapter 10. In Chapter 11, Varney and Pearson address the multifaced provisions protecting the right of people with disabilities to access and use different means of transport. That chapter also reflects on the centrality of transport to realizing the full enjoyment of human rights for persons with disabilities. In Chapter 12, Sganga provides a diachronic analysis of the regulatory solutions adopted by the EU legislator from 2001 to date, to ensure access to copyrighted works to people with disabilities. While discussing the limits and the strengths of Article 5(3)(b) of the InfoSoc Directive (2001/29/EC) $)^{35}$ and its national implementation, Chapter 12 also provides a timely account of the Directive and Regulation implementing the Marrakesh Treaty, ${ }^{36}$ enacted in 2018. ${ }^{37}$ Chapter 13, authored by Charitakis, discusses the accessibility of goods

35 Directive 2001/29/EC on the harmonization of certain aspects of copyright and related rights in the information society [2001] OJ L167/10.

36 Directive (EU) 2017/1564 on certain permitted uses of certain works and other subject matter protected by copyright and related rights for the benefit of persons who are blind, visually impaired or otherwise print-disabled and amending Directive 2001/29/EC on the harmonisation of certain aspects of copyright and related rights in the information society [2017] OJ L242/6; Regulation (EU) 2017/1563 on the cross-border exchange between the Union and third countries of accessible format copies of certain works and other subject matter protected by copyright and related rights for the benefit of persons who are blind, visually impaired or otherwise print-disabled [2017] OJ L242/1.

37 Marrakesh Treaty to Facilitate Access to Published Works for Persons Who Are Blind, Visually Impaired or Otherwise Print Disabled, VIP/DC/8 REV (2013). 
and services more generally, with a focus on the European Accessibility Act. ${ }^{38}$ In Chapter 14, Hosking discusses EU standardization policy as a key instrument in the pursuit of accessibility in the EU. Chapter 15, written by Bovis, analyses the extent to which EU public procurement law encompasses disability concerns and promotes the rights of persons with disabilities. In Chapter 16, Piernas López examines the way in which EU law affects (and regulates) public services aimed at persons with disabilities. That chapter looks at Article 106 TFEU and its implementation, in order to foster an understanding of the role of the EU in that regard. Chapter 17, co-authored by Ferri and Piernas López, analyses whether the Commission, in exercising State aid control, has streamlined national funding towards the implementation of the CRPD, focusing on the derogations contained in Articles 107(2) and 107(3) TFEU, and on the Commission Regulation (EU) 651/2014 - better known as the General Block Exemption Regulation (GBER). ${ }^{39}$ Chapter 18, authored by McEvoy, discusses Structural and Investment Funds, and focuses on the extent to which disability considerations have been mainstreamed into relevant EU legislation. Chapter 19, written by Casarosa, examines the protection of the rights of disabled consumers, and discusses the most recent developments in the field. In Chapter 20, Conte discusses the rights of asylum seekers with disabilities, reflecting on the ongoing reform of EU asylum legislation.

Part III of the Research Handbook includes miscellaneous contributions that examine relevant developments in EU external relations and other developments that have taken place beyond the boundaries of the EU. Chapter 21, authored by Van den Sanden, addresses disability in EU development cooperation, while Chapter 22, written by Faccio, discusses the extent to which trade agreements concluded by the EU with third countries incorporate disability rights. Chapters 23 and 24, authored by Favalli and Palmisano respectively, look beyond the EU to discuss the ECHR and the European Social Charter (ESC). Those chapters address, in particular, the direct or indirect influence that the Council of Europe's system of human rights protection is having on the EU, as well as the more limited influence that EU law has had on that system. In those chapters, the authors also delineate, more generally, the interplay between the ECHR, the ESC and EU law.

Finally, Broderick and Ferri close this edited collection with a brief reflection on the trends and patterns in current EU disability law, and highlight likely future developments in the way in which the EU protects and promotes the rights of persons with disabilities. L151/70.

38 Directive (EU) 2019/882 on the accessibility requirements for products and services [2019] OJ

${ }_{39}$ Commission Regulation (EU) No 651/2014 declaring certain categories of aid compatible with the internal market in application of Articles 107 and 108 of the Treaty [2014] OJ L187/1. 